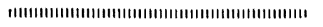

\title{
Report of Transportation Committee of the Joint Research Society of ISIJ
}

\section{Shunta HAYASHI}

\section{1. 概}

\section{要}

運輸部会は，昭和 51 年「鉄鋼業における運輸問題を 扱う部会」として調査部会より独立した部会であるが， 調査部会としての歴史は古く，港湾，輸送などの運輸問 題に間する実態調査にもとづく現状の分析と将来への提 言など，幅広い活動を通じてわが国鉄鋼業の発展に貢献 してきた.

当部会の前身である調杏部会は, 昭和 31 年「運輸, 用水, 環境など時代の要請に応じたテーマを幅広い分野 から取り上げる」こと允目的として設置された部会であ るが，昭和 39 年の第 16 回部会以後は運輸関係のテー マを継続的に取り上げており, 運輸問題は今後とも引続 き取り上げるテーマであることから, 運輸部会の設立と なつたものである.なお, 調査部会のほうは, 日本鉄鋼 業の技術力の現状分析ほかをテーマに新たな活動を開始 している.

当部会で取り上げてきた共通議題を表 1 に示すが，こ れらの議題はいずれもその時々の要請にもとづくもので ある.すなわち, 調査部会として運輸問題に取組んだ当 初は, 高度成長期であつたこともあり, 主として原料岸 壁能力などの港湾問題が取り上げられた。その後は，製 品の構内輸送, トラック輸送および海上輸送などの輸送 時における過密の問題あるいは品質確保の問題が取り上 げられた.この間の部会活動の特筆すべき事項として, 昭和 48 年より足掛 2 年間, 輸出鋼材船内保定小委員会 を設置し，日本船主協会の協力も得て検討を行なつた 「輸出鋼材船内保定作業の標準作成」があげられる.こ の報告書は，関係各方面の強い要望により，英訳版「A Working Standard for the Stowage and Securing of Export Steel Cargoes」も刊行され有効に活用されてい る.

運輸部会として独立して後は，鉄鋼業が安定成長期に 入つてきたこともあり, 輸送関係の整備, 合理化に重点
を置き活動を行なつてきた、尗なわち，昭和 51 年の第 1 回運輸部会では流通基地に関するアンケート結果およ び製品荷役省力化に関する事例発表をもとに活発な討論 が行なわれた。昭和 52 年度は, 構内輸送検討小委員会 を設置し，構内輸送の合理化に関する提言を行なつた。 昭和 53 年度は, 原料荷役検討小委員会を発足させ原料 荷役の現状と省力化についての検討を行なつている.

\section{2. 運輸部会の運営状況}

部会は原則として年 1 回秋に開催され, 毎回の参加者 は 70〜80 名である. 部会参加会社は, 現在 7 社（新日 本製鉄，日本鋼管，川崎製鉄，住友金属，神戸製鋼，日 新製銅および中山製鋼）であり，部会長には代々通商産 業省基礎産業局製鉄課長がその任にあたつている。

部会の議題は, 共通議題, 自由議題および定期交換資 料からなる。共通議題は会員各社の希望のうちから選択 された共通テーマについて「実態調査をもとにした現状 の分析と今後の方向についての提言」を行なうことを目 的としている. 自由議題は会員の「現場に直結した諸問 題の解決」の為の改善事例発表を行なつている.

共通議題の運営は彷来, 部会のテーマ, 提出資料の立 案，計画，検討，まとめなど部会における発表に関する ほとえどを幹事会で行なつてきたが，第 2 回運輸部会以 後は, 小委員会を設置して行なう方法に変更している. すなわち, 幹事会で年度テーマの立案を行なつた後は, 各社第一線の運輸部門担当者で小委員会を編成し, 一年 間の活動が行なわれ，報告書は部会にて発表される．部 会は各議題の発表の場であるとともに情報交換および討 論の場であり，議題によつてはグループ討議が行なわれ る.あわせて，工場見学会が催される.

なお，定期交換資料は当部会の伝統的な統計資料であ り，この種の資料としては業界唯一のものである.

以下に最近の部会活動の主要議題と, 主要成果を要約 して紹介する.

* 日本鉄鋼協会共同研究会運輸部会長 通商産業省基礎産業局製鉄課長 (Chairman of Transportation Committe of the Joint Research Society of ISIJ) 
表 1 運輸部会共通議題テーマ

\begin{tabular}{|c|c|c|}
\hline & & 共通 議 題 \\
\hline \multicolumn{3}{|l|}{ 一調査部会一 } \\
\hline \multirow[t]{3}{*}{ 第 16 回 (39 年 11 月) } & (1) & $\begin{array}{l}\text { 成品工場-仕訳場-捠出し間 } \\
\text { の輸送分析 }\end{array}$ \\
\hline & $(2)$ & 無軌道化 \\
\hline & ( 3 ) & 船内荷役の機械化 \\
\hline \multirow[t]{3}{*}{ 第 17 回 (40 年 4 月) } & $(1)$ & 構内輸送 \\
\hline & $(2)$ & 高温物輸送 \\
\hline & (3) & 原料専用岸壁能力調査 \\
\hline \multirow[t]{2}{*}{ 第 18 回 $(40$ 年 10 月 $)$} & (1) & 轱内輸送 \\
\hline & $(2)$ & 原料専用岸壁能力調査 \\
\hline \multirow[t]{3}{*}{ 第 19 回 (41 年 8 月) } & (1) & 原料岸壁能力調査 \\
\hline & $(2)$ & 港湾現況（各社報告） \\
\hline & (3) & アンローダ仕様 \\
\hline \multirow[t]{4}{*}{ 第 20 回 (42 年 3 月) } & $(1)$ & 成品輸送基礎調査 \\
\hline & (2) & 積付技術について \\
\hline & (3) & 原料岸壁能力調査 \\
\hline & $(4)$ & 港湾現況（まとめ） \\
\hline 第 21 回 $(42$ 年 10 月) & (1) & $\begin{array}{l}\text { 製品の構内輸送工程調査 } \\
\text { (各社報告) }\end{array}$ \\
\hline \multirow[t]{3}{*}{ 第 22 回 (43 年 12 月) } & (1) & $\begin{array}{l}\text { 製品の構内輸送工程調査 } \\
\text { (まとめ) }\end{array}$ \\
\hline & $(2)$ & トラック輸送（中間報告） \\
\hline & ( 3 ) & $\begin{array}{l}\text { プッシャーバージ方式の現 } \\
\text { 況 }\end{array}$ \\
\hline \multirow[t]{3}{*}{ 第 23 回 (45 年 3 月) } & $(1)$ & トラック輸送（まとめ） \\
\hline & $(2)$ & 成品の構内輸送 \\
\hline & $(3)$ & $\begin{array}{l}\text { 鉄鋼輸出船の現状の問題点 } \\
\text { と将来の方向 }\end{array}$ \\
\hline 第 24 回 (46 年 6 月) & $(1)$ & $\begin{array}{l}\text { 鉄鋼輸出船問題の検討 } \\
(\mathrm{LASH} \text { 経済性 } \\
\text { について) }\end{array}$ \\
\hline 第 25 回 (47 年 7 月) & $(1)$ & $\begin{array}{l}\text { 原料岸壁における環境整備 } \\
\text { 対策の検討 }\end{array}$ \\
\hline 第 26 回 (48 年 7 月) & $(1)$ & $\begin{array}{l}\text { 製品沿岸荷役設備ならびに } \\
\text { 作業努率の検討 }\end{array}$ \\
\hline 第 27 回 (49 年 7 月) & $(1)$ & $\begin{array}{l}\text { 国内海上輸送に関する改善 } \\
\text { 事例 }\end{array}$ \\
\hline \multirow[t]{2}{*}{ 第 28 回 $(50$ 年 10 月) } & $(1)$ & トラック輸送 \\
\hline & $(2)$ & $\begin{array}{l}\text { 輸出鋼材船内保定小委員会 } \\
\text { 㓑告 }\end{array}$ \\
\hline \multicolumn{3}{|l|}{ 一運輸部会一 } \\
\hline \multirow[t]{2}{*}{ 第 1 回 $(51$ 年 10 月) } & (1) & 流通基地の実態 \\
\hline & (2) & $\begin{array}{l}\text { 製品荷役作業における省力 } \\
\text { 化 }\end{array}$ \\
\hline 第 2 回 $(52$ 年 10 月) & (1) & 構内輸送の合理化実態 \\
\hline 第 3 回 (53 年 11 月) & $(1)$ & $\begin{array}{l}\text { 原料荷役の現状と省力化に } \\
\text { ついて }\end{array}$ \\
\hline
\end{tabular}

\section{3. 最近の活動状況}

\section{1 荤輸統計資料（定期資料について）}

\section{$3 \cdot 1 \cdot 1$ まえがき}

定期交換資料の作成は，昭和 40 年の第 17 回調査部 会に打いて審議され，第 18 回部会より採択された. 当 時鉄鋼業界共通の課題であつた輸送問題の改善と輸送費 低減を目的として，各製鉄所の情報交換を毎年一定の様 式に従つて行なうこととなつたものである.

当資料には, 設備調査表, 運輸量調査表, 原単位およ び作業量調査表, クレーン作業表, 岸壁クレーン配置図 および泊地水深図が報告されている.

\section{$3 \cdot 1 \cdot 2$ 粗鋼生産量と運輸量の概要}

過去 10 年間の 7 社 21 製鉄所における集約結果を表 2 に示す. これによると昭和 42 年度からピークの昭和 48 年度に至る 7 年間に粗鋼生産は 2.4 倍, 敷地面積は 1.8 倍, 輸送能力は 2.3 倍, 構内輸送量は 2.2 倍と飛 躍的に伸びてきたが，これには設備の大型化および輸送 ロットの拡大によつて対処してきた. しかし，昭和 48 年 10 月のオイルショック以後の急激な需要の減退によ つて各社とも減産を余儀なくされた結果, 昭和 48 年以 後粗鋼生産量は 89\% と大幅に低下したが，敷地面積運 搬設備能力については微增となつている.

\section{$3 \cdot 1 \cdot 3$ 輸送諸原単位}

輸送能率および運搬方法については, 表 3 に示すよう に発足当初に対して各社とも改善の跡が顕著であり，粗 鋼トン当り構内輸送量は昭和 48 年度に $25 \%$ 低下した. しかし低下傾向は昭和 48 年まであり以後上昇傾向を示 与，これは急激な生産落ち込みに対し長期契約の原料輸 入量が追随できず原料在庫が増えてアンバランスになつ たものと推定される.（図 1 )

また手段別輸送割合は，比較的高能率低コストのベル トコンベアーおよび船舶輸送割合が増加し，貨車輸送割 合が減少した。（図 2)

\section{$3 \cdot 1 \cdot 4$ 今後の課題}

現在鉄鋼業界は，大幅な需要低下によつて生産設供の 休止，又は稼動率低下に追い込まれており，輸送部門に おいても新鋭の輸送設備がフルに活用されていない.

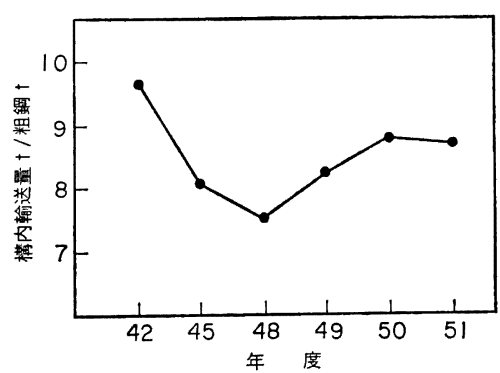

図 1 粗鋼生産トン当り構内輸送量 
表 2 粗鋼生喾量と運輸量

\begin{tabular}{|c|c|c|c|c|c|c|c|}
\hline 項目 $\quad$ 年 度 & 単 位 & $\begin{array}{l}\text { 昭 和 } \\
42 \text { 年度 }\end{array}$ & 45 & 48 & 49 & 50 & 51 \\
\hline 教地面积 & 千 $\mathrm{m}^{2}$ & 59001 & 74774 & 97842 & 103500 & 106880 & 114242 \\
\hline 粗鋼生産量 & $\mp \mathrm{t}$ & 49237 & 75822 & 93743 & 93157 & 83276 & 86658 \\
\hline 速搬能力 & F $\mathrm{t}$ & 485 & 722 & 945 & 921 & 929 & 1024 \\
\hline 檴内輸送量 & 千 $\mathrm{t}$ & 320669 & 607008 & 699906 & 761294 & 729219 & 753378 \\
\hline 総入荷量 & 千 $\mathrm{t}$ & 136379 & 210274 & 247423 & 266194 & 247643 & 247040 \\
\hline 総出荷量 & 千 $\mathrm{t}$ & 56974 & 88361 & 93743 & 93157 & 83276 & 86658 \\
\hline
\end{tabular}

表 3 輸送諸原単 位

\begin{tabular}{|c|c|c|c|c|c|c|c|c|c|}
\hline \multicolumn{3}{|c|}{ 項 目 } & 単 位 & 42 & 45 & 48 & 49 & 50 & 51 \\
\hline \multicolumn{3}{|c|}{ 粗銅トン当り敷地面栍 } & $\mathrm{m}^{2}$ & 1.2 & 1.1 & 1.0 & 1.1 & 1.3 & $1 .^{3}$ \\
\hline \multicolumn{3}{|c|}{ 苓庫面皘/教地面皘 } & $\%$ & 9.1 & $11.0^{\circ}$ & 10.2 & 10.4 & 10.4 & 10.4 \\
\hline \multicolumn{3}{|c|}{ 構内輸送量/粗鋼生産 } & $\mathrm{t}$ & 9.7 & $8 .{ }^{\circ}$ & 7.5 & 8.2 & 8.8 & $8 .^{7}$ \\
\hline \multirow{6}{*}{$\begin{array}{l}\text { 手 } \\
\text { 段 } \\
\text { 別 } \\
\text { 輸 } \\
\text { 送 } \\
\text { 割 } \\
\text { 合 }\end{array}$} & 入 & 貨車 & $\%$ & 5.8 & $4 .^{2}$ & 2.9 & $2 .{ }^{\circ}$ & 2.2 & 2.1 \\
\hline & 出 & トラック & $\%$ & 6.6 & 7.4 & 6.6 & 5.8 & 5.6 & 5.9 \\
\hline & 荷 & 船 舶 & $\%$ & 87.6 & 88.4 & 90.5 & $92 .{ }^{2}$ & 92.2 & $92 . .^{\circ}$ \\
\hline & 蓝 & 貨車 & $\%$ & 47.2 & 46.6 & 43.8 & 42.4 & $38 . .^{\circ}$ & 38.5 \\
\hline & $\begin{array}{l}\text { 内 } \\
\text { 輸 }\end{array}$ & トラック & $\%$ & $24.0^{\circ}$ & $22 .{ }^{7}$ & 23.6 & 23.7 & 24.5 & 24.6 \\
\hline & 送 & ベルトコンペアー & $\%$ & 28.8 & 30.7 & 32.6 & 33.9 & 37.5 & 36.9 \\
\hline
\end{tabular}

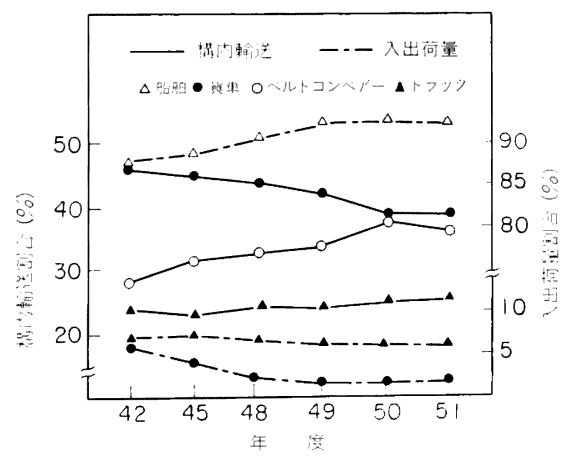

汹 2 手段別輸送割合

往つて輸送原単位も上昇し，かつ固定费負担增がコス トを压迫する要因となつている.

今後急速な回復が望めない現状においては，適正な在 庫量の維持と伴せて, 低能率の旧設備を統廃合して新鋭 高能率設備の稼動率を上げるとともに，徹底した輸送手
段の合理化などにより，輸送能率を向上させることが必 要であろう.

\section{2 輸出鋼材船内保定小委員会報告（昭和 50 年 10 月）}

$3 \cdot 2 \cdot 1$ まえがき

加工貿易国日本の鉄鋼業にとつて鋼材輸出の重要性は いまさら言うまでもないが，その輸出鋼材は全量船積み されて海外各国へ輸送されている.

輸出鋼材の本船積込みに際し, 船内で行なわれる保定 作業, 寸なわち船艙への積付けおよび荷固め作業はミル 側からは裂品品質保護のため, また船会社側からは長距 煀海上㡏送の安全のため共に必要欠くべからざる重要な 作業である。

しかも，船内保定作業には多大な労働力と費用を要し ており, 鋼材輸出量の増大と資材費, 人件費の高騰に対 処するため各社共その対策を検討する必要があつた.

ここに過剩荷固めを是正し，船積作業の能率向上とコ スト切下げに寄与するため, 当委員会が設置され昭和 48 年 12 月より昭和 50 年 2 月にわたつて「保定用資材の 
適正化と荷固め作業標準の確立」を目標として活動を展 開したので，その概要を述べる.

\section{$3 \cdot 2 \cdot 2$ 輸出鋼材船内保安作羓の現況}

当時, 輸出鋼材の船内保安作業は同一鋼材でも各社各 ミルでそれだれ異なつた篗性，異なつた方法で実施され ており，また船積条件，船長によつても差があり，これ に多くの資材と労力を費しているのが実態であつた。

同時に，必ずしも「必要にして充分」というもつとも 合理的な作業方法が実施されていないところが多く, か たや揚地においても，荷解きと使用済資材の処理に多く の労力と時間を費している状況にあつた。

これはミル側, 船会社側双方のベースになる保定作業 標準がないここが大きな要因であり，その必要性が関倸 者の間で高まりつつあつた。

\section{$3 \cdot 2 \cdot 3$ 輸出鋼材船内保定作業標準の検討}

船内保定作業標㔼は各ミル 2 ～ 3 人の専門家をメンバ 一とする当委員会および各ミル荷役業者グループで検討 し, 日本船主協会, 日本海事検定協会ならびに船䅡作業 関倸者の協力の下に作成した鉄鋼各社共通の統一された 作業標準である.

もちろん, 海上輸送中の安全と荷伤み防止を第一戔と して検討したが，海上における皘荷の力学的現秏は複雑 をきわめ，従来なされている考察も経験的票素が多分に あり，その解明は非常に困難である.

したがつて，本作業標準の作成に当つては現状荷閁め 中若干の力学検討は加えてあるが, 経䮖的に最息と思わ れる方式を採用したものである.

その構成は鋼材の品種区分として, 鋼管, コイル, 切 板, 厚板, 条鋼, 線材, スラブ別として各鋼材の特性を 考虑し，また単一鋼材のみの箖付けを対象にした保定作 業標準上なつている。

さらに，付録1として，稓付け荷固め作業のための䛔 準的な保定用木材（ダンネージ）の一覧表およびラッシ ング用資材寸法一覧表を付録として，鋼管の船積段数計 算式とダメージの種類を記述してある.

その後, 日本船主協会に翻訳を依頼し英交の作業標準 A Working Standard for the Stowage and Securing of Export Steel Cargoes」を作成した。これより外国船 船長上の対応が可能となつた。

なお，ミル側および船会社側からの立場より検討した ので，揚地における問題はあまり考虑しておらず特に最 近問題規されている使用済资材の処理という倠点からは 別途アプローチする必要がある.

次に, 期待効果としては保定費用の削減, 保定方法の バラッキ是正による製品品質保蓝の向上および安全輸送 の確保等があるが，現在のところ具体的に把握し得る状 況に至つていない.

これは積付の最終責任権限は本船船長が有するため本 作業標準はあくまでもケースパイケースで処置されるこ
と，および船䑪形状，数種の錩材积合せの状況などによ り保定方法が变化することから簡単に測定し鹳いことに よるものである.

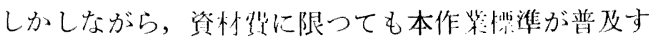
ることにより $50 \%$ 程度の削減が期待され，今後遂次そ の効果があらわれてくるものと考えられる.

最後に, 今後, 船底パネルの強度実験なよ゙による考察 に加え，航海中の荷固め状態の追跡検討を重社ると同時 に力学的理諭に裏づけされたものとし，遂次最少资材， 最少労力で作業効率良く目的を達しうる作業標準を確立 すべく努力していきたいと考えている.

\section{3 流通基地の実態調査報告（昭和 51 年 10 月）}

\section{$3 \cdot 3 \cdot 1$ 概 要}

鉄鋼業における製品輸送は，近年製品の量的拡大，大 型化に伴い，ますます重要度を増してきており，その流 通システムに打いてストック機能, 納入調整およびサー ビス機能を受け持つ流通拠点（基地）の重要性は極めて 高くなつてきている.

鉄鋼各社はこの流通基地について各社各様の方針で基 地の改善，増強に取り組てできたが，ここでは今後も重 要性の高い流通基地の実態を共通項でとら元, 各地の状 況を整理するとともに今後の流近基地体制を指向寸る上 での基礎的资料収集を目的とし，以下の調查を行つた.

\section{$3 \cdot 3 \cdot 2$ 物流拠点体制}

（1）流通形態の比較

流通基地を形態別に分類すると，次のように分類され る.

流通基地 A 大消費地域（闒束·中部·近筩）への大 量物流に対応寸るための自営 (準自営) 基地で, 流通基 地のメインになりつつある. 各メ一カーの立地条件, 需 要地域及び品種との関係など一概に比較はできないが， 日本鋼管及び住友金属が特に基地止没及び集約が進んで いる。

流通基地 B 流通基地 $\mathrm{A}$ に匹敵歺る取扱量があり，新 日本製鉄，神戸製鋼及び日新製鋼はメインになつてい る. 一基地当りの报量からみると小規模であるが数が多 く, 流通基地 $\mathrm{A} の$ 補完的地位にあり, 流通基地 $\mathrm{A}$ の立地 しにくい地方については代替譏能を果たしている.

一般中継港 原則的には, 中継作業のみ行なわせてい る.一般港又は一般河岸であり，流通基地 $\mathrm{A} ， \mathrm{~B}$ の補完 的拠点である 北海道は土地が広大であり，需要地が点 在しており，室蘭製鉄所（新日本製鉄）以外は寸べて 海上輸送となる関係から，中継港が多いのが特色であ る.

商社倉庫及び需要家河岸商社蒼床を山継物流拠点と して利用しているものは非常に少なく，新日本製鉄，住 友金属，神戸製鋼の計 12 ケ所のスである。斎社倉庫あ るいは需要家河岸に直納されるケースは各メーカーと も各地に存在し，各メ一カ一の工場立地あるいは受注 
ロット品種によつて 各社各様に異なり，比較困難であ る.

$3 \cdot 3 \cdot 3$ 主要流通基地の概要

(1) 設備仕様概要

各社基地設備の概要は, 基地により相違点はあるもの の, 规模, 仕梯面とも類似しており, 作業方法は, ほと えどの基地が LLC または RTCの岸壁走行クレーンに より水切し，庫内 OHC にて入庫および出庫作業をす るオーソドックスな方法である.

(2) 運営会社の概要

調査 28 基地のうち, 自社（鉄銅会社）運営は 3 基地 しかなく, 大部分の基地が系列荷役会社により運営され ている. また各社の運営会社起用方法は下記の 3 つの型 に大別できる.

運営会社単一型：川崎製鉄, 住友金属は川鉄倉庫, 住 友埠頭に一本化されており，自社資本参加度はそれぞれ 40\%，100\% である.

運営会社複数型：新日本製鉄は千葉上新潟に自社運営 基地をもち，その他地区については各地域ごとに官公庁 と合同出資の荷役会社を起用し，その出資比率は $10 \%$ 〜30\% である. 日本鋼管も各地域ごとに 50\%〜100\% 出資の荷役会社を設置している.

運営会社海運型 : 神戸製銅, 日新製鋼は系列の海運元 請会社を基地運営会社として起用し，その資本参加度は $50 \%$ 程度である。

(3) 人員楧成

基地における平均的な嬂務別人員比率は管理嬂 $5 \%$, 事務職 30\%，現業職 60\%，その他 $5 \%$ である.

全社別（自地, 元請, 下請別）人員比率については, ほとえどの基地が元請会社に基地運営を依存している関 倸で，鉄鋼会社員が駐在している基地は少ない，また元

\section{表 4 流通基地 $\mathrm{A}$ 一覧表}

\begin{tabular}{|c|c|c|c|}
\hline $\begin{array}{l}\text { 新 } \\
\text { 日 } \\
\text { 本 } \\
\text { 製 } \\
\text { 鉄 }\end{array}$ & 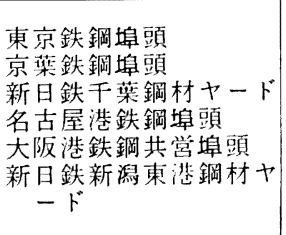 & $\begin{array}{l}\text { 住 } \\
\text { 友 } \\
\text { 金 } \\
\text { 属 }\end{array}$ & 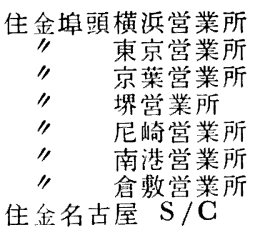 \\
\hline \multirow{2}{*}{$\begin{array}{l}\text { 日 } \\
\text { 本 } \\
\text { 鋼 } \\
\text { 管 }\end{array}$} & \multirow{2}{*}{$\begin{array}{cc}\text { 日本鋼管仙台垍頭 } \\
\text { " } & \text { 市川埠頭市川 } \\
\text { " } & \text { 市川埠頭本牧 } \\
\text { " } & \text { 大井川埠頭 } \\
\text { " } & \text { 名古屋垖頭 } \\
\text { " } & \text { 鉄鋼倉庫堺 } \\
\text { " } & \text { 鉄鋼會庫平林 }\end{array}$} & $\begin{array}{l}\frac{\text { 神 }}{\text { 户 }} \\
\text { 製 } \\
\text { 鋼 }\end{array}$ & $\begin{array}{l}\text { 横浜鉄鋼サービスセン } \\
\text { ター } \\
\text { 市川鉄鋼サービスセン } \\
\text { ター }\end{array}$ \\
\hline & & $\begin{array}{l}\text { 日 } \\
\text { 新 } \\
\text { 製 } \\
\text { 鋼 }\end{array}$ & $\begin{array}{l}\text { 日新製鋼桜島スチール } \\
\text { センター }\end{array}$ \\
\hline $\begin{array}{l}\text { 川 } \\
\text { 崎 } \\
\text { 製 } \\
\text { 鉄 }\end{array}$ & $\begin{array}{ll}\text { 東京サービスセンター } \\
\text { 大阪 } \\
\text { 市川 } \\
\text { 仙台 } & \text { " }\end{array}$ & & \\
\hline
\end{tabular}

請と下請会社の人員比率は基地によつて大差があるが平 均すると $50: 50$ である.

\section{4 粠内翰送検討小委員会報告（昭和 52 年 10 月）}

\section{$3 \cdot 4 \cdot 1$ まえがき}

高度成長期に, 既存立地製鉄所の生産設備増強を, 余 儀なくされたため, 当初計画レイアウドの変更をもたら し, 構内輸送面からは大部分の製鉄所が問題をかがて いる現状である. 一方, 運輸部門は, ミルの効率を追求 する生産サイドと, 種々多椂な製品受渡を要求する需要 サイドの接点に位置し, このため, 実作業には形態の複 雑さと波動性がもたらされている.

小委員会は，このレイアウト及び，実作業の両面から 来る制約条件の中で, 輸送機器及びその利用方法の改善 置場の利用方法, あるいは要員の削減, 請負化の促進等 々コスト削減のために行なわれている各社それぞれの合 理化, 効率化の実態をある共通項でとらえて, これを比 較し, その大要を明らかにするとともに, 今後各社が改 善，合理化を更に追求する上での基礎資料を提供すると いう目的で活動を行つた。

\section{$3 \cdot 4 \cdot 2$ 調查対象}

品 種...鉄龬一次製品全般とし, 原料, 素材, 半成品 は原則として除外, 但し, 厚板, 熱延の次工 程素材で製品と同様の輸送荷役を伴うものは 対象とした.

範 囲…形状合格又は梱包以降の輸送, 保管, 荷役で 工場から最終出荷便への積込までとした。

期 間 $\cdots 52$ 年 1 月〜 3 月の間とし, 最も標準に近い 任意の月とした.

製鉄所…新日本製鉄：八幡，広畑，君津，日本鋼管： 福山, 京浜, 川崎製鉄 : 水島, 千葉, 住友金 属 : 和歌山, 鹿島, 神戸製鋼 : 加古川, 日新 製錩：吳, 中山货鋼：船町 以上 12 製鉄所

\section{$3 \cdot 4 \cdot 3$ 調查内容}

（1）便, 品種別製品出荷実態

製品の出荷輸送手段は, 製鉄所の立地条件, 品種構成 などに依り選択されている。そして，これらの特街はそ の製鉄所の荷役設備及び作業体制全般に影響を与えてい るはずであり, 当実態調査資料の背景をなすものとして 調查した.

（2）製品置場とハンドリング機器の能力・効率実態 a . 置場能力比較

品種を厚板, ストリップ, その他に大別し, 置場有 効面積当り何 $\mathrm{t}$ 出荷しているか, 逆にい光ば出荷量に 対してどの程度の置場があるかを比較するため, 月間 出荷量＼cjkstart有効面積でみた.

\section{b. 置場効率比較}

置場効率を, 置場能力 $\mathrm{t} / \mathrm{m}^{2}$ (有効面皘), 扱い量の $\mathrm{t} / \mathrm{M}$.H. (延工数), 置場回転率 (=月間投量 $\div$ 在庫能 力 $\mathrm{t})$ で比較. 
表 5 主要品種別滞留日数

\begin{tabular}{|c|c|c|c|c|c|}
\hline \multirow{2}{*}{ 主要品種 } & \multirow{2}{*}{\multicolumn{2}{|c|}{$\begin{array}{l}\text { 輸 出 } \\
\text { 国 }\end{array}$}} & \multicolumn{3}{|c|}{ 滞 留 日 数 } \\
\hline & & & Min. & Max. & Ave. \\
\hline 厚 & $\begin{array}{l}\text { 輸 } \\
\text { 国 }\end{array}$ & $\begin{array}{l}\text { 出 } \\
\text { 内 }\end{array}$ & $\begin{array}{r}13 \\
9\end{array}$ & $\begin{array}{l}40 \\
20\end{array}$ & $\begin{array}{l}33 .{ }^{3} \text { 日 } \\
14 . .^{\circ}\end{array}$ \\
\hline 熱延製品 & $\begin{array}{l}\text { 輸 } \\
\text { 国 }\end{array}$ & $\begin{array}{l}\text { 出 } \\
\text { 内 }\end{array}$ & $\begin{array}{r}14 \\
6\end{array}$ & $\begin{array}{l}46.5 \\
14.5\end{array}$ & $\begin{array}{r}26.1 \\
9.6\end{array}$ \\
\hline 冷延製品 & $\begin{array}{l}\text { 輸 } \\
\text { 国 }\end{array}$ & 出 & $\begin{array}{r}13 \\
7\end{array}$ & $\begin{array}{l}38 \\
22\end{array}$ & $\begin{array}{l}26.8 \\
15.4\end{array}$ \\
\hline 条 & $\begin{array}{l}\text { 輸 } \\
\text { 国 }\end{array}$ & $\begin{array}{l}\text { 出 } \\
\text { 内 }\end{array}$ & $\begin{array}{c}19.2 \\
6\end{array}$ & $\begin{array}{l}50 \\
31.9\end{array}$ & $\begin{array}{l}30 \\
14.5\end{array}$ \\
\hline 大径鋼 管 & $\begin{array}{l}\text { 輸 } \\
\text { 国 }\end{array}$ & 出 & $\begin{array}{l}26.5 \\
10\end{array}$ & $\begin{array}{l}36 \\
37\end{array}$ & $\begin{array}{l}30.2 \\
32.1\end{array}$ \\
\hline 小中径鋼管 & $\begin{array}{l}\text { 輸 } \\
\text { 国 }\end{array}$ & $\begin{array}{l}\text { 出 } \\
\text { 内 }\end{array}$ & $\begin{array}{l}18.5 \\
18\end{array}$ & $\begin{array}{l}34 \\
33\end{array}$ & $\begin{array}{l}29.7 \\
22.4\end{array}$ \\
\hline
\end{tabular}

最短最長は所単位, 平均は 12 制鉄所平均

c. その他

製品置場屋内外比率比較, 品種別設備比較, 及び, 品種別吊具及び人員配置等を比較した。

（3）品種別平均滞留日数

滞留日数の長短は, 在庫の増減につながり, 置場での 選別配替作業などの置場効率に影響をもたらす. 又, 在 庫金利削減のために, 滞留日数の短縮は各社努力してお り, 各社の滞留日数がどの位か, あるいはどの様な対策 を採つているかの若干の考察を討みた。

(4) 構内における輸送実態

構内における輸送の問題として, 使用機器（保有台数 仕樣, 効率, 運行管理システム), 輸送量 (量, 距離, 夕 イミング, 目的). ハンドリング (輸送機器への積卸, 置 場内での配替, 品質上の問題) 等々であるが, これらは レイアウトの実態によつて大きく左右される問題でもあ る.ここでは構内輸送に使用されている機器は, どの様 なものが，どの程度利用されているか, 能力面から輸送 機器の大型化について若干の考察をした.

刃, 輸送量を生産量に対する比率で指数化し,「輸出 倍率」という形で評価し，ハンドリング回数とともに， 各製鉄所の効率化の実態を比較した。

\section{（5）船積作業の実態}

船積作業の荷役能率は, 荷役設備, 吊単重, 要員, 船 型及び, レイアウト（置場から岸壁への距離, 輸送方法 の差による浜出し作業能率）などにより変動する。ここ では, ギャング当りの皘能率 $(\mathrm{t} / \mathrm{h})$, 要員削減の効率 管理指標としての T/M.H.の比較を討みた。

(6) アンケート調查

構内輸送関係のデータのみでは, 出てこない製品管理 に関する考元方, 運営方法についてアンケート方式で各
装 6 ハンドリング回数及び輸送倍邀

\begin{tabular}{|c|c|c|c|c|}
\hline \multirow{2}{*}{ 品 種 } & \multicolumn{2}{|c|}{ ハンドリング回数 } & \multicolumn{2}{|c|}{ 輸 送 倍 摔 } \\
\hline & Min. & Max. & Min. & Max. \\
\hline 厚板 & 1.6 & 5.5 & 0.76 & 2.64 \\
\hline & 0.4 & 3.8 & 0.23 & 1.70 \\
\hline & 1.6 & 3.9 & 0.31 & 1.50 \\
\hline & 1.7 & $4 .^{4}$ & 0.66 & 2.16 \\
\hline & 2.33 & 4.0 & 1.17 & 2.0 \\
\hline 線 棒 & 1.2 & 3.5 & 0.19 & 1.47 \\
\hline 全製品 & - & - & 0.58 & 1.81 \\
\hline
\end{tabular}

1）榆送機器による移動を対象としてわり，ブラント輸送（クレーン， コンベアー, 自走台审, フォークリフト)は含んでいない,

2）製鉄所の輸送倍率は全製品トータルで 1.3 前後となつている.(単 純平均)

3）輸送倍率の高低に影罄を与える要素は，直出荷比率，仕期品帢送， 會実の立地形贸，ブラント輸送比率が考えられる。

製鉄所の各設問に対する対応を分類整理した。

\section{5 原料荷役検討小委員会報告（昭和 53 年 11 月）}

\section{$3 \cdot 5 \cdot 1$ まえがき}

昭和 40 年代初めから半ばにかけての最新鋭の大型臨

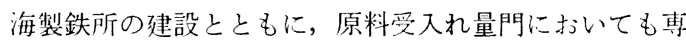
用船の大型化，港湾・荷役設備の大型化が図られてき た。そこで，これら大型化された原料受入れ設備（海上 からの受入れに限る）の実態について集約するとともに 咋今の長期景気低迷による低操業・設備余剩下での原料 入荷実態, 諸設備の合理的運用, 粉塵・漏油などの環境 保全対策及び改善事例などについて, 各製鉄所の現況を まと的，今後の合理化・改善推進の一助とした。

$3 \cdot 5 \cdot 2$ 諸設備の大型化

(1) 岸壁クレーン: 主原料バースには, 公称能力 $1500 \sim 2000 \mathrm{t} / \mathrm{h}$ ，岸壁からのアウト・リーチ 25〜44 $\mathrm{m}$ の橋型クレーンを, 副原料バースには, 公称能力 200 $\sim 700 \mathrm{t} / \mathrm{h}$ の水平引込式クレンを，ほとえどの製鉄所が 上架している。また，水平引込式クレーンは，常に広範 に上架されている。一方，橋型クレーンでは，昭和 45 年頃ロープトロリー式クレーンが数多く上架されたのに 対し, 昭和 48 年ごろからの更新・新設には, クラブト ロリー式クレーンが上架される傾向にある.さらに，ク レーン本体の大型化とともに，一量製鉄所では，クレー ン運転のコンピューター制御, 自動化を討行しつつあ る.

（2）港湾設備及び入港条件

港湾設備は，最大水深 $27 \mathrm{~m}$ を有する新日本彆鉄（大 分）のシーバースを初めとして，外航バースでは15〜20 $\mathrm{m}$, 内航バースでは 6 9m の水深が普通となつている. また, 岸壁長は, 高炻容積比で $1 \mathrm{~m}$ 当り $12 \mathrm{~m}^{3}$ 程度に なつている. 一方, 外航大型船の入港制約条件について は，各製鉄所の立地する海象条件により異なり，乖船水 先人の判断によるところが大きいが，大体の目安として 表7のようになつている. 


\section{$3.5 \cdot 3$ 原料入荷実態}

各製鉄沂一入侕与万愉入原料は 120〜150 千 DWT 型 の，国内原料は5〜10 个 DWT 型の船舶で各々榆送さ れている。亦た，大型船で㡏送されてる輸入原料では1 製鉄所で全量掦切る 1 港揚に限らず，同一会社の $2 \sim 3$ の製鉄所で揚切る多港掦が行なわれている. それは，入 港隻数比で鉱石：60\% 弱, 石炭 : $25 \%$ 前後文られ, 各 製鉄所間の港湾設備のアンバランスをカバーする大型船 の効率的配船運用の跡がうかがえる。

$3 \cdot 5 \cdot 4$ 荷役担当部門

製鉄所内で荷役を担当する部門は，製鉄部門に属する ところと, 製品荷役をも担当している運輸部門として独 立ているところの 2 通りある。また，荷役作業について は，各社とも多注業者入の請負化が進み，本船上での荷 役作業の全てが請目化されており，クレーン運転の一部 と管理部門が直営に止まるにすぎない，クレーン運転作 業から船内サラ工作業までの荷役にたずさわる人数は, 鉱石で 1 船当り 20〜 25 人，棚吊り現象の生じやすい石

表 7 入港が制約される場合

\begin{tabular}{|c|c|c|}
\hline & & 条 件 内 容 \\
\hline \multicolumn{2}{|c|}{ 余裕 水 深 } & $\begin{array}{cl}\text { 航路水深が } & 15 \mathrm{~m} \text { 以下: } 0 \mathrm{~m} \text { 未満 } \\
\text { " } & 15 \sim 18 \mathrm{~m}: 1 \mathrm{~m} \text { " } \\
\text { " } & 18 \mathrm{~m} \text { 以上: 本船吃水の } \\
& 10 \% \text { 未満 }\end{array}$ \\
\hline 風 & 速 & $10 \sim 15 \mathrm{~m}$ 以上 \\
\hline 波 & 莎 & $1 \sim 2 \mathrm{~m}$ 以上 \\
\hline 視 & 程 & $1000 \sim 2000 \mathrm{~m}$ 以下 \\
\hline 潮 & 流 & 想流前後各 1 時間を除く時間带 \\
\hline \multirow{2}{*}{ 夜間 } & 入港 & 日没以降 \\
\hline & 出港 & $20: 00 \sim 21: 00$ 以降 \\
\hline \multicolumn{2}{|c|}{$\begin{array}{l}\text { 使用タグ・ボ } \\
\text { 一ト馬力 }\end{array}$} & 本船 DWT の $10 \%$ 以下の出力 (PS) \\
\hline
\end{tabular}

炭で 1 船当り 25 ～ 30 人となつている.

$3 \cdot 5 \cdot 5$ 環境保全対策

昭和 46〜47 年以降の環境保全気運の高まりの中で, 原料荷役関係でも, 粉鷹・睎音防止, 海洋污染防止の為 に，諸々の対処を行なつている，その主なものでは，

・アンローダーホッパーロ，ヤードでの散水実施

・ベルト・コンベアーへのカバー取付け

・クレーンへの落鉱防止板・防風板の取付け

・军かし構造岸壁の床張り実施

・オイルフュンスの展張実施

などがあげられる。

\section{$3 \cdot 5 \cdot 6$ 改善及び今後の問題点}

各製鉄所は，与件の立地条件・設備環境の中で各々に 作業改善を鋭意推進中であるが，各社共通にかかえる問 題は表 9 のよおりである. いずれの問題も従来から取り 上げられているものであり，種々の改善策が試行されて いるが，全面的問題解決にまで至つていない.さらに， 街来，製鉄所所内に埋立処理していた産業廃棄物やスラ グの有効利用によるバラスなど，大量のばら物を皘出す

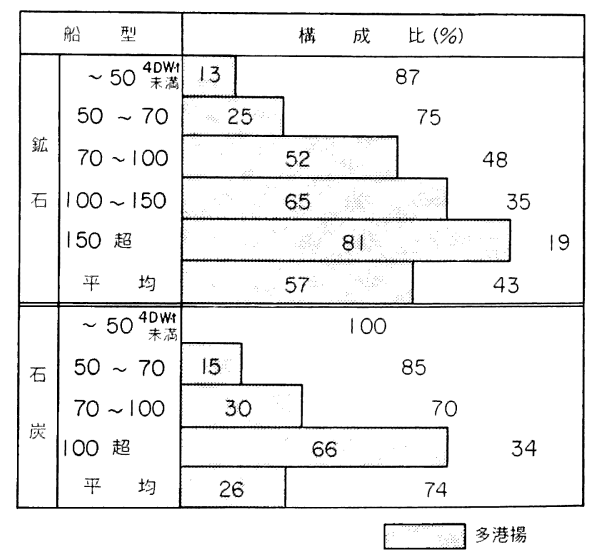

図 3 入港隻数比による多港揚比率

表 8 鉄鋼関係専用船保有量

\begin{tabular}{|c|c|c|c|c|c|c|c|c|c|c|c|c|c|}
\hline 年 & 船型規模 & $\begin{array}{l}3 \\
\text { 万 } \\
\text { 末 } \\
\text { 満 }\end{array}$ & $\begin{array}{l}3 \\
? \\
4 \\
\text { 万 } \\
\text { 級 }\end{array}$ & $\begin{array}{l}5 \\
? \\
6 \\
\text { 万 } \\
\text { 級 }\end{array}$ & $\begin{array}{c}7 \\
? \\
8 \\
\text { 方 } \\
\text { 級 }\end{array}$ & $\begin{array}{c}9 \\
? \\
10 \\
\text { 万 } \\
\text { 級 }\end{array}$ & $\begin{array}{c}11 \\
? \\
12 \\
\text { 万 } \\
\text { 級 }\end{array}$ & $\begin{array}{c}13 \\
\text { ? } \\
14 \\
\text { 万 } \\
\text { 級 }\end{array}$ & $\begin{array}{c}15 \\
\text { ? } \\
16 \\
\text { 万 } \\
\text { 級 }\end{array}$ & $\begin{array}{c}17 \\
? \\
18 \\
\text { 万 } \\
\text { 級 }\end{array}$ & $\begin{array}{c}19 \\
\text { ? } \\
20 \\
\text { 万 } \\
\text { 級 }\end{array}$ & $\begin{array}{l}21 \\
\text { 万 } \\
\text { 以 } \\
\text { 上 }\end{array}$ & 計 \\
\hline $\begin{array}{l}\text { 昭 } \\
45 \\
\text { 年 }\end{array}$ & 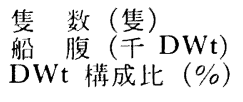 & $\begin{array}{r}32 \\
676 \\
8.1\end{array}$ & $\begin{array}{r}29 \\
1165 \\
14 . .^{\circ}\end{array}$ & $\begin{array}{r}50 \\
2380 \\
28.5\end{array}$ & $\begin{array}{r}19 \\
1482 \\
17.8\end{array}$ & $\begin{array}{r}22 \\
2164 \\
25.9\end{array}$ & $\begin{array}{r}3 \\
345 \\
4.1\end{array}$ & $\begin{array}{r}1 \\
136 \\
1.6\end{array}$ & $\begin{array}{l}- \\
- \\
-\end{array}$ & $\begin{array}{l}- \\
- \\
-\end{array}$ & $\begin{array}{l}- \\
-\end{array}$ & $\begin{array}{l}- \\
-\end{array}$ & $\begin{array}{r}156 \\
8348 \\
100\end{array}$ \\
\hline $\begin{array}{l}\text { 昭 } \\
51 \\
\text { 年 }\end{array}$ & 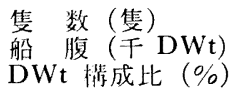 & $\begin{array}{r}2 \\
42 \\
0.3\end{array}$ & $\begin{array}{r}16 \\
633 \\
4.6\end{array}$ & $\begin{array}{r}41 \\
2408 \\
17.4\end{array}$ & $\begin{array}{r}11 \\
856 \\
6.2\end{array}$ & $\begin{array}{r}20 \\
2024 \\
14.7\end{array}$ & $\begin{array}{r}22 \\
2550 \\
18.5\end{array}$ & $\begin{array}{r}6 \\
818 \\
5.9\end{array}$ & $\begin{array}{r}20 \\
3230 \\
23.4\end{array}$ & $\begin{array}{r}3 \\
550 \\
4.0\end{array}$ & $\begin{array}{l}- \\
- \\
-\end{array}$ & $\begin{array}{r}3 \\
692 \\
5.0\end{array}$ & $\begin{array}{r}144 \\
13804 \\
100\end{array}$ \\
\hline
\end{tabular}

（鉄速：鉄鋼緒計要臨 1977 年版） 
表 9

\begin{tabular}{|c|c|}
\hline 問 題 点 & 改善 状 況 \\
\hline $\begin{array}{l}\text { 船内\#ラェ作業, 棚落 } \\
\text { 乙作業の省力化及代 } \\
\text { 治具の考案 }\end{array}$ & 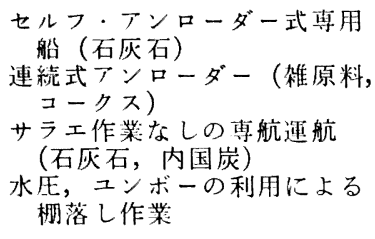 \\
\hline $\begin{array}{l}\text { 落鉱処理, 岸壁ヤード } \\
\text { の清掃問題 }\end{array}$ & $\begin{array}{l}\text { ベルト裹の水洗 } \\
\text { ロード・ス利用 } \\
\text { 皘地散水の実施 } \\
\text { 落鉱処理と修理部門の一元化 } \\
\text { による責任の明確化 }\end{array}$ \\
\hline $\begin{array}{l}\text { 波動性の大きい荷役作 } \\
\text { 業の吸収策 }\end{array}$ & $\begin{array}{l}\text { 標準工数の設定 } \\
\text { 雑作業・製品荷役作箱とのプ } \\
\quad \text { ル・多能工化 }\end{array}$ \\
\hline $\begin{array}{l}\text { 大型化したクレーン設 } \\
\text { 備の補修・治具取替 } \\
\text { 等における湆所作業 } \\
\text { の安全性 }\end{array}$ & $\begin{array}{l}\text { ワイヤー, グラブ取替方法の } \\
\text { 改善 } \\
\text { 取替作業台の設置 }\end{array}$ \\
\hline
\end{tabular}

設備・何役方法が，今後クローズアップされてくるであ ろう.

なお，当小委員会は，アンケート方式により各製鉄所 の現況を調査したものであり, その調査対象は, 新日本 製鉄一八幡，大分，名古屋，君津，日本鋼管-福山，京浜， 川崎製鉄-下倠，住友金属-和歌山，麘岛，神戸製銅-加古 川，日新製鋼一点，中山製鋼の 12 製鉄所による.

\section{4.あとが}

運輸部会の活動状況の概要を述べてきたが，鉄鋼業も 安定成長期に入つた現在, 運輸部門における効率的運用 はますます重要な課題となつており，今後更に広籁な分 野にわたつて技術交流をはかり部会活動の成果を上げて いきたい.

なお，当部会の小委員会活動は，その研究成果はもち ろえのこと, 若手管理者の育成, また各社共通問題の認 職拉よ゙部会会員の連带感を深めるという面においても 非常に有意義な活動であると考えており，今後も一層の 充実をはかつていきたい. 